\title{
Evaluation of different methods for saliva collection in young children
}

\author{
Avaliação de diferentes métodos de coleta de saliva em pré-escolares
}

\author{
ALINE LAIGNIER SOARES-YOSHIKAWA ${ }^{1}$ \\ LIVIA RoBERTA PIEDADE DE OLIVEIRA² \\ CARLA MARTINS ${ }^{3}$ \\ IVETE POMARICO RIBEIRO DE SOUSA
}

\begin{abstract}
Objective: Aimed to compare three saliva collection methods in terms of their acceptability by young children, the salivary samples were submitted to total protein concentration measurement and a SDS-Page gel electrophoresis.

Methods: The study was composed of 34 healthy children with complete primary dentition. They were selected from those who presented themselves for dental treatment at the Dental School of a public university in Rio de Janeiro, Brazil. Anamnesis was performed, followed by the saliva collection and intraoral examination for the evaluation of dmf-t index (WHO). After all the salivary collection methods were performed, children were asked about which method of collection they would prefer.

Results: When asked about the preferred method of saliva collection, $50 \%$ of children answered that they prefer to spit into a tube, while $37.5 \%$ had chosen using Salivette ${ }^{\circledR}$ collection device and $12.5 \%$ had opted by using the pipette.

Conclusion: The collection by spitting saliva into a tube can be recommended for saliva collection in young children once the method is well accepted by them and it is not necessary additional cost.
\end{abstract}

Keywords: Saliva. Children. Body fluids. Collection method. Noninvasive.

\section{RESUMO}

Biomarcadores salivares têm sido usados como meio de diagnóstico e monitoramento de doenças. Apesar da vantagem da coleta salivar não ser invasiva nem dolorosa, ela depende da colaboração do paciente.

Objetivo: Este estudo comparou três métodos de coleta salivar (expectoração, pipeta e Salivette®) quanto à aceitação por crianças pré-escolares e avaliou se o método de coleta interfere na composição salivar.

Material e Métodos: A coleta salivar por meio dos três diferentes métodos foi realizada em 34 crianças saudáveis em idade pré-escolar, e após as coletas as crianças foram questionadas sobre qual método mais agradou. As amostras salivares foram analisadas para dosagem de proteína total e realizada a eletroforese em gel.

Resultados: Entre os métodos de coleta salivar, a expectoração foi o preferido por $50 \%$ das crianças, seguido pelo Salivette $®(37,5 \%)$ e pipeta $(12,5 \%)$. Não houve diferença da dosagem de proteína total entre as amostras coletadas pelos diferentes métodos $(p<0,01)$, nem a eletroforese gel mostrou diferença de intensidade entre as bandas de proteínas das amostras dos diferentes grupos.

Conclusão: Conclui-se então que a forma de coleta salivar não interfere na composição da saliva. Como a expectoração foi aceita por metade das crianças e essa não representa custo adicional para a coleta salivar, deve ser indicada. Porém, o emprego de Salivette® precisa ser considerado quando o indivíduo (por exemplo, bebês e pacientes com necessidades especiais) tiver dificuldade para expectorar a saliva.

Palavras-chave: Saliva. Crianças. Fluidos corporais. Método de coleta. Não invasivo.

DDS, MS, PhD student, Piracicaba Dental School, University of Campinas, Piracicaba, SP, Brazil. Limeira Avenue, 901 - Areião, Piracicaba.

2 DDS, MSD, Department of Pediatric Dentistry and Orthodontics, School of Dentistry, Universidade Federal do Rio de Janeiro, Rio de Janeiro, Brazil.

3 DDS, MSD, PhD, Department of Pediatric Dentistry and Orthodontics, School of Dentistry, Universidade Federal do Rio de Janeiro, Rio de Janeiro, Brazil.

4 DDS, MSD, PhD, Full Professor, Department of Pediatric Dentistry and Orthodontics, School of Dentistry, Universidade Federal do Rio de Janeiro, Rio de Janeiro, Brazil. 


\section{Introduction}

Saliva consists on an oral fluid with high potential to measure biological parameters ${ }^{1}$ and, contains a high number of proteins and peptides and these are involved in a multitude of different biological functions in the oral cavity. $^{2}$ As saliva offers researchers great opportunities to measure biomarkers in the body, ${ }^{3}$ it has been considered as the mirror of the human body. ${ }^{4}$ Thus, saliva has been widely studied as means to evaluate risk of disease development, diagnosis and also to monitor disease progression. ${ }^{5}$

Regarding health promotion, a desirable goal is the ability to monitor health and disease of individuals by non-invasive means ${ }^{6}$ and this is possible through salivary analysis, once saliva collection - opposite to blood collection - comprehends a non-invasive and painless method which allows monitoring several biomarkers in infants, children, elderly and non-collaborative subjects. ${ }^{5,7}$ Furthermore, saliva collection presents others advantages, such as, easiness to collect, to transport and to store the sample, requiring non specialized ability of the operator. ${ }^{4,8}$ Moreover, it allows the analysis of proteins, metabolites, pathogens, antibodies, drugs, and nucleic acids. ${ }^{2,9}$ It must also be highlighted that, for the professional, saliva collection is safer than the blood test ${ }^{6}$ and, once saliva collection is not invasive, it reduces the patient's anxiety and discomfort during the collection. Thus, salivary analysis is especially attractive to those who work with children, considering it is a positive alternative to venous blood sampling. ${ }^{10}$

Nevertheless, saliva collection from young children may be not so simple due their difficulty to spit or because they can refuse to participate to the saliva collection. ${ }^{3}$ So, a suggestion for maximizing children contribution to saliva collection is to employ collection methods which can be acceptable by children. ${ }^{3,8}$ Saliva collection devices are widely used for examine many components of the salivary sample. ${ }^{11}$ Several commercial saliva collectors are available, such as Salivette ${ }^{\circledR}$, Orasure ${ }^{\circledR}$ and Omnisal ${ }^{\circledR}$.

Still, it is important to select the method of collecting the saliva sample and investigate the possibility of influence device in concentrations of salivary components. ${ }^{4}$ Thus, the present study aimed to compare three saliva collection methods in terms of their acceptability by young children. The three methods compared were (a) spitting into a tube, (b) use of a pipet to collect saliva deposited at the floor of mouth and (c) use of Salivette ${ }^{\circledR}$ collection device. Moreover, the salivary samples were submitted to an a total protein concentration measurement and a SDS-Page gel electrophoresis.

\section{Methodology}

After receiving the approval of the Local Ethics Committee, 34 healthy children with complete primary dentition were selected from those who presented themselves for dental treatment at the Dental School of a public university in Rio de Janeiro, Brazil. Written informed consent was obtained from all caregivers and verbal consent from the children. Then, anamnesis was performed, followed by the saliva collection and intra-oral examination for the evaluation of dmf-t index (WHO). After all the salivary collection methods were performed, children were asked about which method of collection they would prefer.

\section{Saliva collection}

Children were asked to refrain from eating and drinking one hour prior to saliva collection. Each salivary collection was performed for 2 minutes and during the saliva collection children were comfortably sitted in an upright position. At first, children were asked to spit into a graduated tube each 30 seconds. For the second saliva collection method, the investigator 
used a pipet to collect saliva deposited at the floor of mouth. And the last saliva collection method consisted on using Salivette ${ }^{\circledR}$ collection device which was positioned under children's tongue for 2 minutes and then the saturated Salivette ${ }^{\circledR}$ collection device was placed into the specific Salivette ${ }^{\circledR}$ 's tube to be centrifuge to extract the saliva as recommended by the manufacturer. After saliva collection, the volume of each salivary sample was measured and the samples were centrifuged $(14,000 \mathrm{~g})$ at $4^{\circ} \mathrm{C}$ for $20 \mathrm{~min}$ to remove cellular debris and to minimize the turbidity of saliva, which can negatively impact on the accuracy of analysis. The resulting whole saliva supernatant was separated from the pellet, transferred into an appropriately labelled tube and stored at $-20^{\circ} \mathrm{C}$ until they were analyzed.

\section{Total Protein Concentration}

The total protein concentration of each saliva sample before and after the dialysis procedure was measured using the bicinchoninic acid assay (Thermo Scientific, IL, USA). The assay was performed in a 96-well micro plate according to the manufacturer's protocol and bovine serum albumin protein standard. Total protein concentration was measured spectrophotometrically employing an UV-visible spectrophotometer (Beckman) determining the optical density at a wavelength of $562 \mathrm{~nm}$. All samples were analyzed in duplicate.

\section{SDS-PAGE Gel Electrophoresis}

Two SDS-PAGE procedures were performed as described previously, ${ }^{12}$ both were conducted using a final polyacrylamide concentration of $12 \%$. Both saliva samples and PAGE were treated in the same conditions. Briefly, $30 \mu \mathrm{l}$ of sample buffer was added to a microcentrifuge tube containing the equivalent of $20 \mu \mathrm{g}$ of total protein (Figure 1) for each saliva sample or the equivalent of $20 \mu \mathrm{L}$ (Figure 2) of each saliva sample. The tubes were vortexed for $5 \mathrm{~s}$ at maximum speed and boiled for $5 \mathrm{~min}$. After that, the samples were directly placed into the wells of the stacking gel. A constant voltage of $120 \mathrm{~V}$ was used for the development of electrophoretic separation, and the gel was stained for $16 \mathrm{~h}$ with Coomassie brilliant blue R-250 and destaining in methanol/ acetic acid/ water $(40 / 10 / 60 \% \mathrm{v} / \mathrm{v})$ for $2 \mathrm{~h}$.

\section{Statistical analyses}

The Kolmogorov-Smirnov test was applied to verify the normality of the data. Statistical significance was assessed using one-way ANOVA and Tukey's tests $(\alpha=5 \%)$ for the comparisons between the groups (SPSS 20.0 software, IBM, Chicago, USA). A $p$ value < 0.05 was considered statistically significant difference. The present study was approved of the Local Ethics Committee of the Federal University of Rio de Janeiro, on the 12th of march 2013 (CAAE: 18575813.4.0000.5257).

\section{Results}

A total of 34 healthy children (HG) participated in this study, aged from 3 to 6 years old. The present study population was consisted of healthy boys ( $44 \%)$ and girls $(56 \%)$ aging between 3-6 (4.37 \pm 0.80$)$ years old who presented themselves to dental treatment at the Pediatric Dentistry Clinic of a public university is Rio de Janeiro, Brazil (Table 1).

Table 1: Characterization of study participants.

\begin{tabular}{l|c}
\hline Parameters & $\begin{array}{c}\mathrm{HG} \\
\mathrm{n}=34\end{array}$ \\
\hline Boys (\%) & 44 \\
\hline Girls (\%) & 56 \\
\hline Caries-free children (\%) & $31.3 \%$ \\
\hline dmf-t index & $5.30 \pm 0.94$ \\
\hline Presence of oral manifestations (\%) & $9 \%$ \\
\hline
\end{tabular}


The intra-oral examination pointed out that the dmf-t index mean was $5.30 \pm 0.94$. When asked about the preferred method of saliva collection, $50 \%$ of children answered that they prefer to spit into a tube, while $37.5 \%$ had chosen using Salivette ${ }^{\circledR}$ collection device and $12.5 \%$ had opted by using the pipette.

Regarding to the volume of saliva collected by different methods, a higher volume was obtained when the children were asked to spit into a tube each 30 seconds $(1.66 \pm 1.40 \mathrm{~mL})$, followed by the use of Salivette ${ }^{\circledR}$ collection device $(1.08 \pm 0.76 \mathrm{~mL})$. A lower saliva volume was derived from collection using pipette $(0.50 \pm 0.24 \mathrm{~mL})$. No significant differences in the saliva volume values were observed between the different methods $(p=0.37)$.

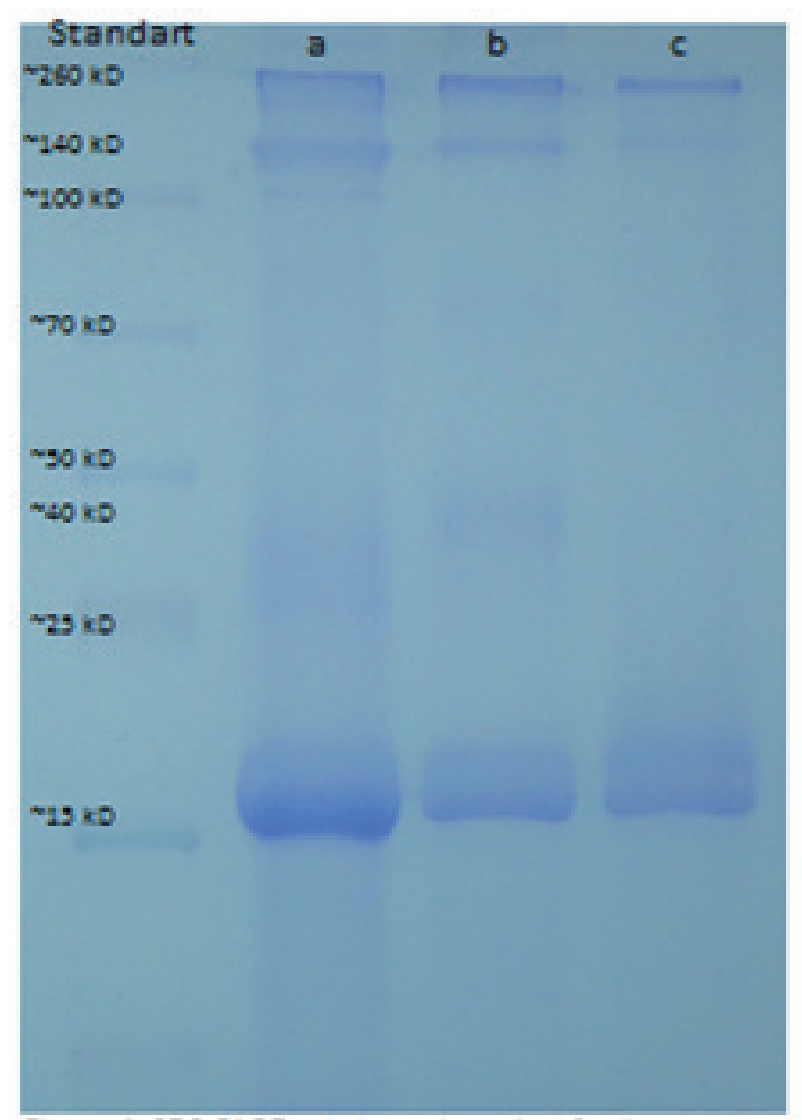

Figure 1: SDS-PAGE gel eletrophoresis of salivary samples collecting by spiting (a), using of pipette (b) and using of Salivette $\AA$ (c) and with the same concentration of total protein $(20 \mu \mathrm{g})$.
Figure 1 shows the SDS-PAGE gel electrophoresis where was applied the same concentration of total protein (the equivalent of $20 \mu \mathrm{g}$ of total protein for each saliva sample) and Figure 2 shows the SDS-PAGE gel electrophoresis where was applied the same volume of salivary sample $(20 \mu \mathrm{L})$. It is possible to observe in both gel that those proteins with low molecular weight are the most common between the salivary samples and that a higher concentration is found at the salivary sample collected by spitting saliva into the tube (that means without using any device for saliva collection).

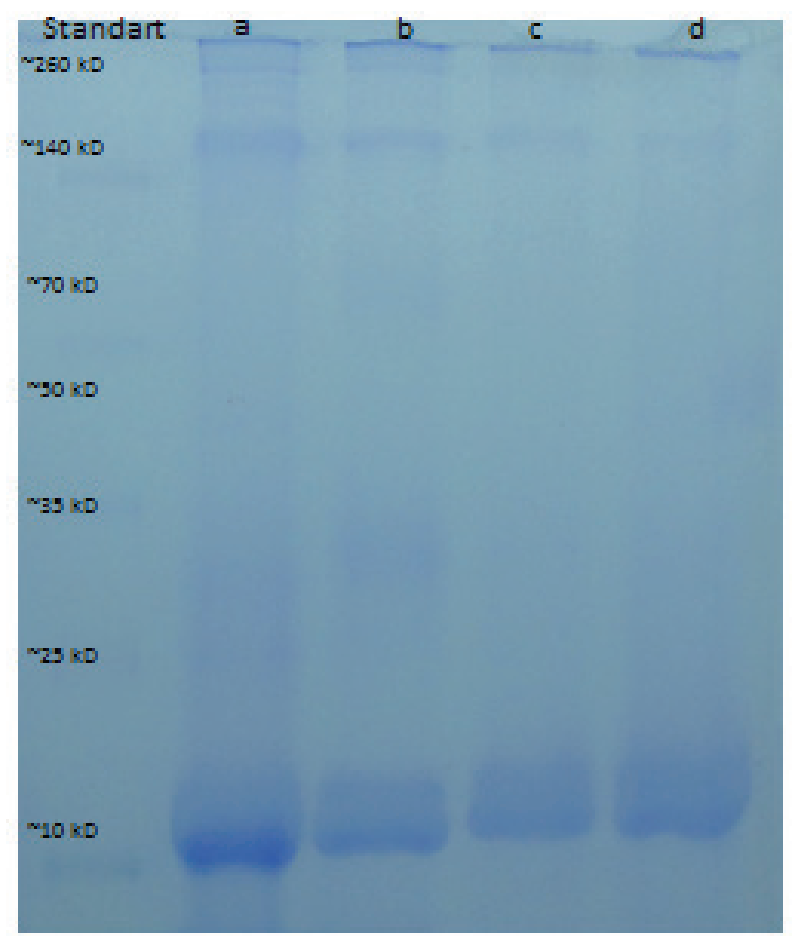

Figure 2: SDS-PAGE gel eletrophoresis of $20 \mu \mathrm{L}$ of salivary sample collected by spiting (a), using of pipette (b), using of Salivette ${ }^{\circledR}$ saliva collection system (c) and using of Salivette saliva collection modified system.

\section{Discussion}

It is well known that saliva is a promising biofluid that can be applied to diagnosis and/ or monitoring health and disease. One of the greatest advantages of this biofluid consists 
on the fact that its collection is painless what facilitates the collection in children. However, as there are several saliva collection methods available, including devices for this purpose, it was investigated the opinion of young children about the favorite method for saliva collection and if there are difference between saliva composition according to the collection method.

The obtained data revealed that $50 \%$ of the children who had taken part on this study had preferred to collect saliva by spiting into de tube, probably, because the act to spit is something familiar to the children, being unnecessary to use devices. Regarding the use of pipette to collect the saliva deposited at the floor of mouth, generally, children felt uncomfortable with its use and one child refused to have saliva collected by this method. On the other hand, the Salivette was not refused by any child, probably, because it is similar to roller cotton. Additionally, a study developed by O'Farrelly \& Hennessy $(2013)^{3}$ evaluated the opinion of children and their parents about the saliva collection method and their parents highlighted the use of Sorbete $\AA$ (a device that works in the same way that Salivette $\AA$ ) as being an easy manner to collect children's saliva and that can be conducted by any adult.

Once the effectiveness of saliva as a diagnostic biological fluid depended on the standardization of the pre-analytical phase, collection and processing methods to deliver the most accurate and meaningful results, beside the patient preference for collection method, it is necessary to establish if the collection method interfere at the saliva composition. So, it is important to emphasize that a reduction in the concentration of the studied components (cortisol and sigA) was found when the saliva was collected by Salivette $\AA$, suggesting that the material used in the cotton
Salivette ${ }^{\circledR}$ may have an absorbance affinity for $\operatorname{sig} A$ molecules in saliva. ${ }^{8}$ Corroborating to this study, our data indicate that some salivary components can be retained at the Salivette $\AA$ once the sample collected by spitting saliva into the tube showed a higher protein concentration at the SDS-Page gel when compared to salivary sample collected through the use of Salivette $®$. Further, after salivary sample centrifugation, a lower amount of pellet could be observed at those samples collected with Salivette $®$. More experiments will be developed in a closer future to verify if the difference was statistically significant.

\section{Conclusion}

The present results reinforce the affirmative that it is important to select the method of collecting the saliva sample and investigate the possibility of influence device in concentrations of salivary components. ${ }^{4}$ So, other saliva analysis techniques, such as nuclear magnetic resonance, will be performed by using different saliva collection methods. However, considering the actual data, collection by spitting saliva into a tube can be recommended for saliva collection in young children once the method is well accepted by them and it is not necessary additional cost. Furthermore, by spitting saliva is possible to observe the volume of saliva collected and to identify when the volume necessary to the analysis is achieved. Nevertheless, using devices as Salivette $\AA$ must be considered for saliva collection from young children and people with special care need who are unable to spit the saliva into the tube.

\section{Disclosure statement}

The authors declare no conflict of interest. 


\section{References}

1. Lee YH, Wong DT. Saliva: an emerging biofluid for early detection of diseases. Am J Dent 2009; 22: 241-8. https://www.ncbi.nlm.nih.gov/ pmc/articles/PMC2860957/

2. Khurshid Z., Zohaib S., Najeeb S., Zafar MS, Slowey PD, Almas K. Human Saliva Collection Devices for Proteomics: An Update. Int $\mathbf{J}$ Mol Sci. 2016; 6; 17 (6). https://doi.org/10.3390/ ijms17060846

3. O'farrelly, C., Hennessy, E. Brief Report: A Comparison of Saliva Collection Methods With Preschool Children: The Perspectives of Children, Parents, and Childcare Practitioners. J Pediatric Nursi. 2013; 28: 292-295. https://doi. org/10.1016/j.pedn.2012.09.005

4. Topkas, E. et al. Evaluation of saliva collection devices for the analysis of proteins. Clin. Chim. Acta. 2012; 413: 1.066-1.070. https://doi. org/10.1016/j.cca.2012.02.020

5. Kaczor-Urbanowicz KE, Martin Carreras-Presas C., Aro K., Tu M., Garcia-Godoy F., Wong DT. Saliva diagnostics - Current views and directions. Exp Biol Med (Maywood), 2017; 242 (5): 459-472. https://doi. org/10.1177/1535370216681550

6. Lee JM, Garon E., Wong DT. Salivary diagnostics. Orthod Craniofac Res. 2009;

12 (3): 206-11. https://doi.org/10.1111 /j.1601-6343.2009.01454

7. Castagnola M., Picciotti PM, Messana I., Fanali C., Fiorita A., Cabras T., Calò L., Pisano E., Passali GC, lavarone F., Paludetti G., Scarano E. Potential applications of human saliva as diagnostic fluid. Acta Otorhinolaryngol Ital. 2011; 31 (6): 347-57. https://www.ncbi.nlm.nih. gov/pmc/articles/PMC3272865/

8. Strazdins, L. et al. Impact of saliva collection methods on slgA and cortisol assays and acceptability to participants. J of Immunoll Meth. 2005; 307: 167-171. https://doi.org/10.1016/j. jim.2005.09.010

9. de Oliveira LR, Martins C., Fidalgo TK, Freitas-Fernandes LB, de Oliveira Torres R., Soares AL, Almeida FC, Valente AP, de Souza IP. Salivary Metabolite Fingerprint of Type 1 Diabetes in Young Children. J Proteome Res. 2016; 15 (8): 2491-9. https://doi.org/ 10.1021/acs. jproteome.6b00007

10. Kiess, W., Pfaeffle, R. Steroid analysis in saliva: a noninvasive tool for pediatric research and clinical practice. J Pediatr. 2007; 83 (2): 97-99. https://doi.org/10.2223/JPED.1605

11. Golatowski C., Salazar MG, Dhople VM, Hammer E., Kocher T., Jehmlich N., Völker U. Comparative evaluation of saliva collection methods for proteome analysis. Clin Chim Acta. 2013; 18; 419: 42-6. https://doi.org/10.1016/j. cca.2013.01.013

12. Thomadaki K., Helmerhorst EJ, Tian N. Sun X., Siqueira WL, Walt DR, Oppenheim FG. Whole-saliva proteolysis and its impact on salivary diagnostics. J Dent Res. 2011; 90 (11): 1.325-30. https://doi. org/10.1177/0022034511420721

Submetido em: 5-6-2019

Aceito em: 6-2-2020 